\title{
Seasonal and interannual phytoplankton production in a sub-Arctic tidewater outlet glacier fjord, SW Greenland
}

\author{
Thomas Juul-Pedersen ${ }^{1, *}$, Kristine E. Arendt ${ }^{1}$, John Mortensen ${ }^{1}$, \\ Martin E. Blicher ${ }^{1}$, Dorte H. Søgaard ${ }^{1,3}$, Søren Rysgaard ${ }^{1,2,4}$ \\ ${ }^{1}$ Greenland Climate Research Centre, Greenland Institute of Natural Resources, PO Box 570, 3900 Nuuk, Greenland \\ ${ }^{2}$ Centre for Earth Observation Science, CHR Faculty of Environment Earth and Resources, University of Manitoba, \\ 499 Wallace Building, Winnipeg, MB R3T 2N2, Canada \\ ${ }^{3}$ University of Southern Denmark, Campusvej 55, 5230 Odense M, Denmark \\ ${ }^{4}$ Arctic Research Centre, Aarhus University, C. F. Møllers Allé 8, 8000 Aarhus C, Denmark
}

\begin{abstract}
This study describes seasonal patterns and proposes likely drivers of an unusual phytoplankton primary production pattern in the outer-sill region of a tidewater outlet glacierinfluenced fjord (Godthåbsfjord) in SW Greenland. It is based on monthly measurements of pelagic primary production and hydrographic conditions during a $7 \mathrm{yr}$ period. Total annual primary production during 2005 to 2012 was between 84.6 and $139.1 \mathrm{~g} \mathrm{C} \mathrm{m}^{-2} \mathrm{yr}^{-1}$. Two phytoplankton blooms of similar magnitude reoccur in the fjord every year. A 'classical' spring bloom of up to $1743 \mathrm{mg} \mathrm{C} \mathrm{m}^{-2} \mathrm{~d}^{-1}$ occurred in late April/early May in a water column almost fully mixed due to tidal forces at the fjord sill. After the spring bloom, primary production decreased in June, after which a summer bloom of up to $1383 \mathrm{mg} \mathrm{C} \mathrm{m}^{-2} \mathrm{~d}^{-1}$ built up. This bloom coincided with the development of a pycnocline caused by substantial runoff from the Greenland Ice Sheet every year during midsummer. This observation supports a hypothesis that fjord circulation modes and subglacial freshwater discharge, leading to upwelling of nutrient rich water, stimulate primary production in the fjord. Future changes in the timing or magnitude of meltwater runoff from the Greenland Ice Sheet are thus likely to affect phytoplankton dynamics in the fjord.
\end{abstract}

KEY WORDS: Phytoplankton production - Seasonal patterns - Time series - Glacial meltwater · Sub-Arctic fjord · Greenland

\section{INTRODUCTION}

The marine ecosystems along the west coast of Greenland are considered highly productive, sustaining large pelagic and benthic communities across trophic levels. Primary production estimates from West Greenland coastal waters (26 to $500 \mathrm{~g} \mathrm{C} \mathrm{m}^{-2}$ $\mathrm{yr}^{-1}$; Steeman-Nielsen 1975, Smidt 1979, Andersen 1981, Jensen et al. 1999, Levinsen \& Nielsen 2002) are in the high end of values recorded in Arctic seas (ranging from 5 to $900 \mathrm{~g} \mathrm{C} \mathrm{m}^{-2} \mathrm{yr}^{-1}$; Stein \& Mac-

${ }^{*}$ Corresponding author: thpe@natur.gl donald 2004), particularly on the Arctic shelf regions (average estimates of 32, 97 and $>230 \mathrm{~g} \mathrm{C} \mathrm{m}^{-2} \mathrm{yr}^{-1}$ for Arctic Shelves, Atlantic Sector and Bering Shelf, respectively). Primary production in high-latitude waters is mainly driven by phytoplankton, while seaice algae may be of seasonal importance in areas experiencing seasonal sea ice $(<1-66 \%$ of total marine primary production; Legendre et al. 1992, Rysgaard \& Glud 2007) and benthic algae and macroalgae may contribute significantly or even dominate primary production in shallow areas within the pho-

(C) The authors 2015. Open Access under Creative Commons by Attribution Licence. Use, distribution and reproduction are unrestricted. Authors and original publication must be credited. 
tic zone (Glud et al. 2002, 2010, Krause-Jensen et al. 2007, Attard et al. 2014).

High-latitude coastal ecosystems display a pronounced seasonal succession in community structure, function and productivity (Carmack \& Wassmann 2006) due to the prominent seasonality in environmental conditions (e.g. sea ice, light, temperature and salinity; Sakshaug 2004). Still, the majority of studies on pelagic primary production have focused on the peak productive periods in spring and/or summer, while only few studies cover the entire annual cycle including the less productive winter and autumn months (Smidt 1979, Andersen 1981, Levinsen \& Nielsen 2002). Timing and duration of the primary productive season in Arctic regions is ultimately determined by light availability, i.e. the seasonal incoming solar radiation (insolation) in relation to the latitude of observation (Sakshaug 2004, Leu et al. 2011) combined with snow and sea-ice cover reducing light penetration into the water column (Rysgaard \& Glud 2007, Søgaard et al. 2010). Factors controlling the magnitude of primary production are more complex due to variable bathymetry, hydrographic conditions and nutrient availability (Stein \& Macdonald 2004, Tremblay et al. 2006, 2008), species composition (Grøntved \& Seidenfaden 1938, Poulsen \& Reuss 2002, Coello-Camba et al. 2014) and grazing pressure during the productive season (Levinsen et al. 2000, Madsen et al. 2008, Arendt et al. 2010, Calbet et al. 2011, Tang et al. 2011).

This study investigated the complete annual cycle of phytoplankton production in a sub-Arctic fjord in the course of a $7 \mathrm{yr}$ period with the aim of identifying reoccurring patterns and discussing possible drivers of seasonal production. The study was conducted in the outer-sill region of a tidewater outlet glacierinfluenced fjord (Godthåbsfjord, SW Greenland) connected to the Greenland Ice Sheet (see Fig. 1). Freshwater originating from melting sea ice and glacial ice along with terrestrial meltwater runoff has been shown to induce a seasonal stratification of the upper part of the water column, which is further strengthened by solar heating and air-sea heat exchange during summer (Mortensen et al. 2013). Stratification of the water column may impose counteracting effects on the phytoplankton community by favouring their suspension within the photic zone while at the same time may limit the input of new nutrients across the pycnocline (Tremblay et al. 2006, 2008). Freshwater input therefore has an important influence on phytoplankton productivity in fjords and coastal systems. Mortensen et al. $(2011,2014)$ identified interannual variation in circulation modes of a tidewater outlet glacier fjord, with implications for water mass distribution and water exchange between fjord and the coastal region, a factor which may influence phytoplankton distribution and productivity. In general, little is known about how terrestrial and glacial runoff affects phytoplankton production within Greenland fjords. In this study we report on seasonal and interannual variation in phytoplankton primary production, chlorophyll a (chl a) concentrations, nutrient concentrations and hydrographic conditions at the entrance of the subArctic Godthåbsfjord, SW Greenland. Our study is based on monthly phytoplankton production and biomass data, along with hydrographic and chemical data, from 2005 to 2012.

\section{MATERIALS AND METHODS}

\section{Study area}

The Godthåbsfjord system, SW Greenland, is a fjord system made up of a number of fjord branches. The fjord system covers $2013 \mathrm{~km}^{2}$ with an average depth of ca. $250 \mathrm{~m}$ (max. depth $>600 \mathrm{~m}$; Mortensen et al. 2011). The main fjord branch is approximately $190 \mathrm{~km}$ long and several sills characterize the outer part of the fjord. Incoming solar radiation at this subArctic latitude varies greatly during the year with day length (i.e. sun above the horizon) ranging from ca. 4 to $20 \mathrm{~h}$ during an annual cycle. The fjord system is connected to the Greenland Ice Sheet via 3 tidewater outlet glaciers and several rivers. The Godthåbsfjord system is affected by significant tides (tidal range ca. 1 to $5 \mathrm{~m}$; Richter et al. 2011); during the spring tide $20 \mathrm{~km}^{3}$ of water passes the outer-sill region during a tidal cycle. This volume is of the same order of magnitude as the annual freshwater discharge to the fjord, including both the liquid and solid components (van As et al. 2014). Three principal water masses, atmospheric heat exchange and melt/freeze processes contribute to the water masses found in the fjord (Mortensen et al. 2011, 2013). Two of the 3 principal water masses are found outside the fjord; subpolar mode water and coastal water, whereas the third, freshwater, comes from meltwater runoff from the Greenland Ice Sheet, terrestrial runoff, meltwater from sea ice and calved glacial ice. The freshwater input induces a seasonal stratification of the upper part of the water column, which is further strengthened by solar heating and air-sea heat exchange during summer (e.g. Mortensen et al. 2013). Seasonal sea-ice cover is limited to secondary fjord 


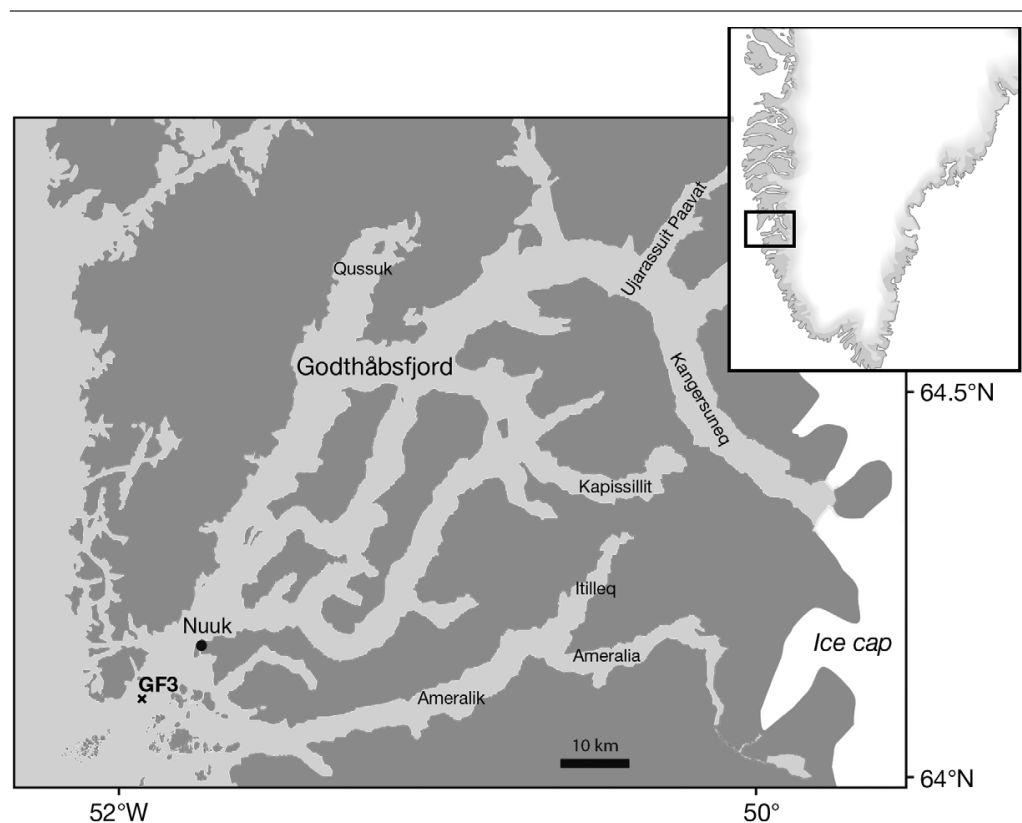

Fig. 1. Godthåbsfjord area, Greenland (inset). The station (GF3) sampled by MarineBasis-Nuuk (2005-2012) is marked by an $\boldsymbol{\star}$

branches and the innermost fjord section contributing to an early freshwater input to the fjord along with terrestrial snow melt. The sampling/monitoring station (GF3) is located at the outer-sill region $\left(64^{\circ} 0^{\prime} 7 \mathrm{~N} 51^{\circ} 53^{\prime} \mathrm{W}\right.$, bottom depth at c. $350 \mathrm{~m}$; Fig. 1), which is characterized by strong and deep-reaching tidal diapycnal mixing.

\section{Seasonal study}

Pelagic sampling at the monitoring station was conducted monthly within the marine monitoring program MarineBasis-Nuuk, part of the Greenland Ecosystem Monitoring program (GEM; www.g-e-m. $\mathrm{dk})$. Vertical profiles of salinity, temperature, irradiance (photosynthetically active radiation, PAR), fluorescence and turbidity were obtained using a CTD profiler (SBE19+) equipped with a Biospherical QSP-2300L PAR sensor, Seapoint chl a fluorometer and a Seapoint turbidity sensor.

Water samples were collected using a Niskin water sampler at 1, 5, 10, 15, 20, 30, 50, 100, 150, 250 and $300 \mathrm{~m}$ depth. Water samples for nutrient analyses were pre-filtered through a GF/C filter, and kept frozen $\left(-18^{\circ} \mathrm{C}\right)$ prior to analysis. Phosphate $\left(\mathrm{PO}_{4}{ }^{3-}\right)$ and silicate $\left(\mathrm{SiO}_{2}\right)$ concentrations were determined by spectrophotometric approach (Strickland \& Parsons 1972, Grasshoff et al. 1983), while nitrate and nitrite $\left(\mathrm{NO}_{3}{ }^{-}+\mathrm{NO}_{2}{ }^{-}\right)$concentrations were measured by vanadium chloride reduction (Braman \& Hendrix 1989).
Particulate phytoplankton primary production was determined using the ${ }^{14} \mathrm{C}$ incubation technique (Steeman-Nielsen 1952). Samples from 5, 10, 20, 30 and $40 \mathrm{~m}$ depth were incubated at in situ depths in glass bottles (2 light and 1 dark bottles at each depth) for ca. $2 \mathrm{~h}$ around noon. Samples were kept completely dark after recovery until GF/C filtration. Then $100 \mu \mathrm{l} 1 \mathrm{M} \mathrm{HCl}$ was added and the samples fumed for a minimum of $12 \mathrm{~h}$ to remove remaining ${ }^{14} \mathrm{C}$, after which PerkinElmer Ultima Gold scintillation liquid was added and mixed well. The samples were analyzed after a minimum of $22 \mathrm{~h}$ using a TriCarb 2800 TR liquid scintillation analyzer (PerkinElmer). Production values were dark-corrected using the dark bottle from each depth. Samples for in situ total inorganic carbon $\left(\mathrm{TCO}_{2}\right)$ concentration, used for calculation of primary production, was collected at corresponding depths in $100 \mathrm{ml}$ glass bottles with a gas-tight tube and preserved with $\mathrm{HgCl}_{2}$ (final concentration of $0.02 \%)$. $\mathrm{TCO}_{2}$ concentrations were measured coulometrically (Johnson et al. 1987). Asiaq (Greenland Survey) supplied irradiance data $\left(\mathrm{W} \mathrm{m}^{-2}\right)$, which was converted to PAR after calibration $\left(\mathrm{R}^{2}=0.99\right.$, $\mathrm{p}<$ $0.001, \mathrm{n}=133$ ) with a LiCor 1400 . Daily primary production was calculated by multiplying the production value from the ca. $2 \mathrm{~h}$ incubation with the ratio between the incoming PAR during the deployment period (ca. $2 \mathrm{~h}$ ) and the entire day of sampling $(24 \mathrm{~h}$ ). Annual primary production estimates were adjusted for differences in daily PAR between each measurement. Primary production was integrated vertically from 0 to $45 \mathrm{~m}$ covering the average depth strata of $\geq 1 \%$ of surface PAR throughout the study $(38.8 \mathrm{~m}$; data not shown).

\section{RESULTS}

\section{Seasonal succession}

A distinct seasonal structure in both hydrographic condition and activity of the primary producers were observed in the $7 \mathrm{yr}$ time series at the outer-sill region (Stn GF3, Fig.1). During winter (November to March), the upper $50 \mathrm{~m}$ of the water column at Stn GF3 was well mixed, due to deep tidal-induced diapycnal mixing in the outer-sill region and low freshwater runoff from the fjord (Fig. 2A). Across all 

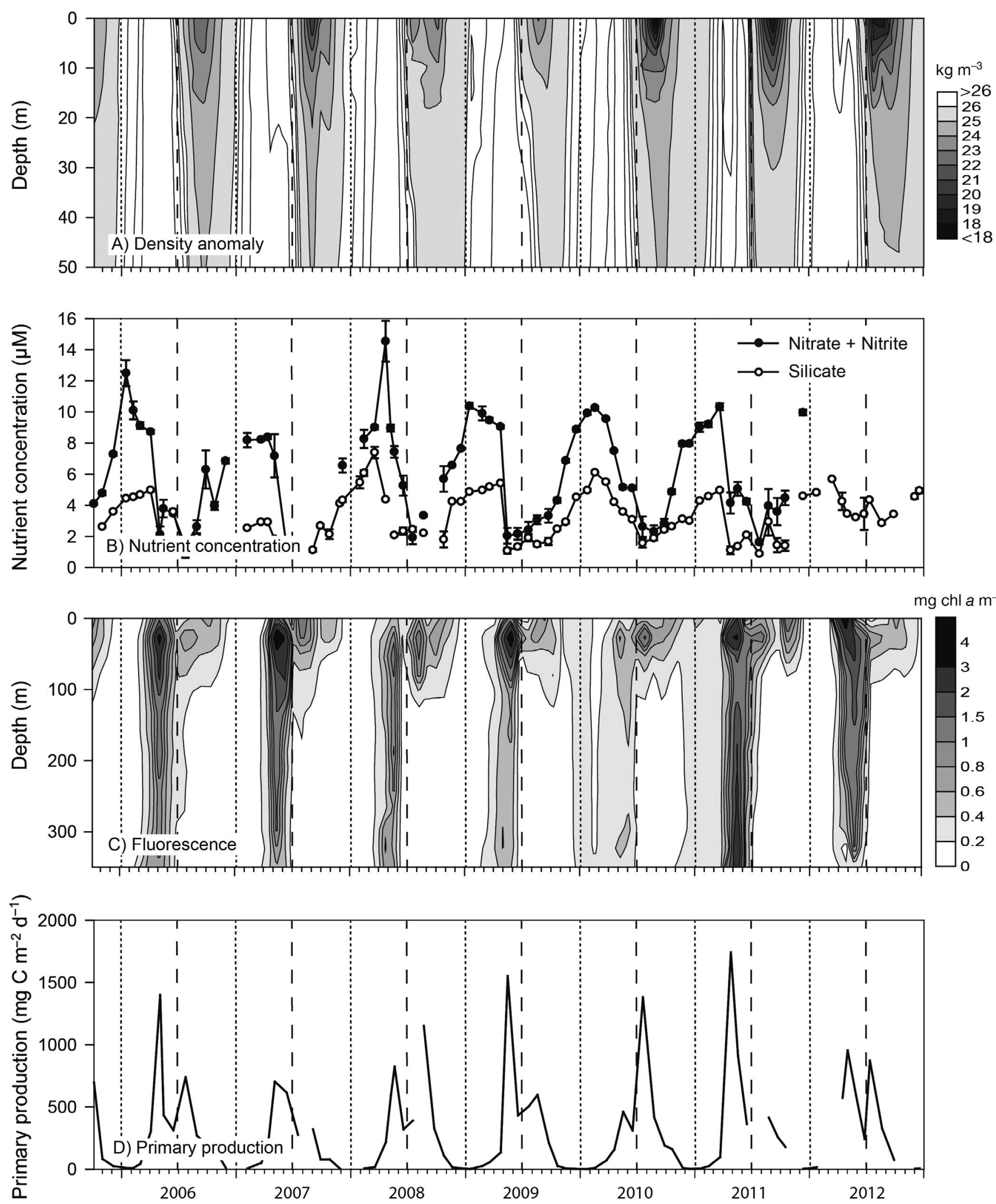

Fig. 2. Time series (2006-2012) of (A) density anomaly $\left(\mathrm{kg} \mathrm{m}^{-3}\right.$ from 0-50 m), (B) mean \pm SE nutrient concentrations (from

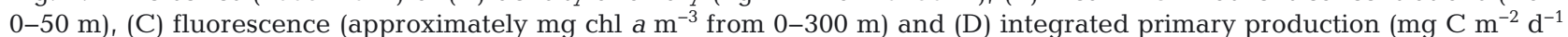
from 0-45 m) at the outer-sill region of Godthåbsfjord (see Fig. 1) 
years, conditions from November to March were characterized by a low phytoplankton biomass

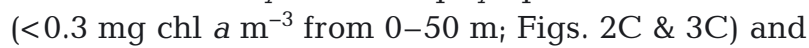
production $\left(<100 \mathrm{mg} \mathrm{C} \mathrm{m}^{-2} \mathrm{~d}^{-1}\right.$; Figs. 2D \& 3A). Biomass and production levels were evenly distributed within the upper $50 \mathrm{~m}$ (Fig. 3B,C). Nutrient concentrations in the upper $50 \mathrm{~m}$ were at their highest during winter, ranging from 6.0-14.6, 2.4-9.6,
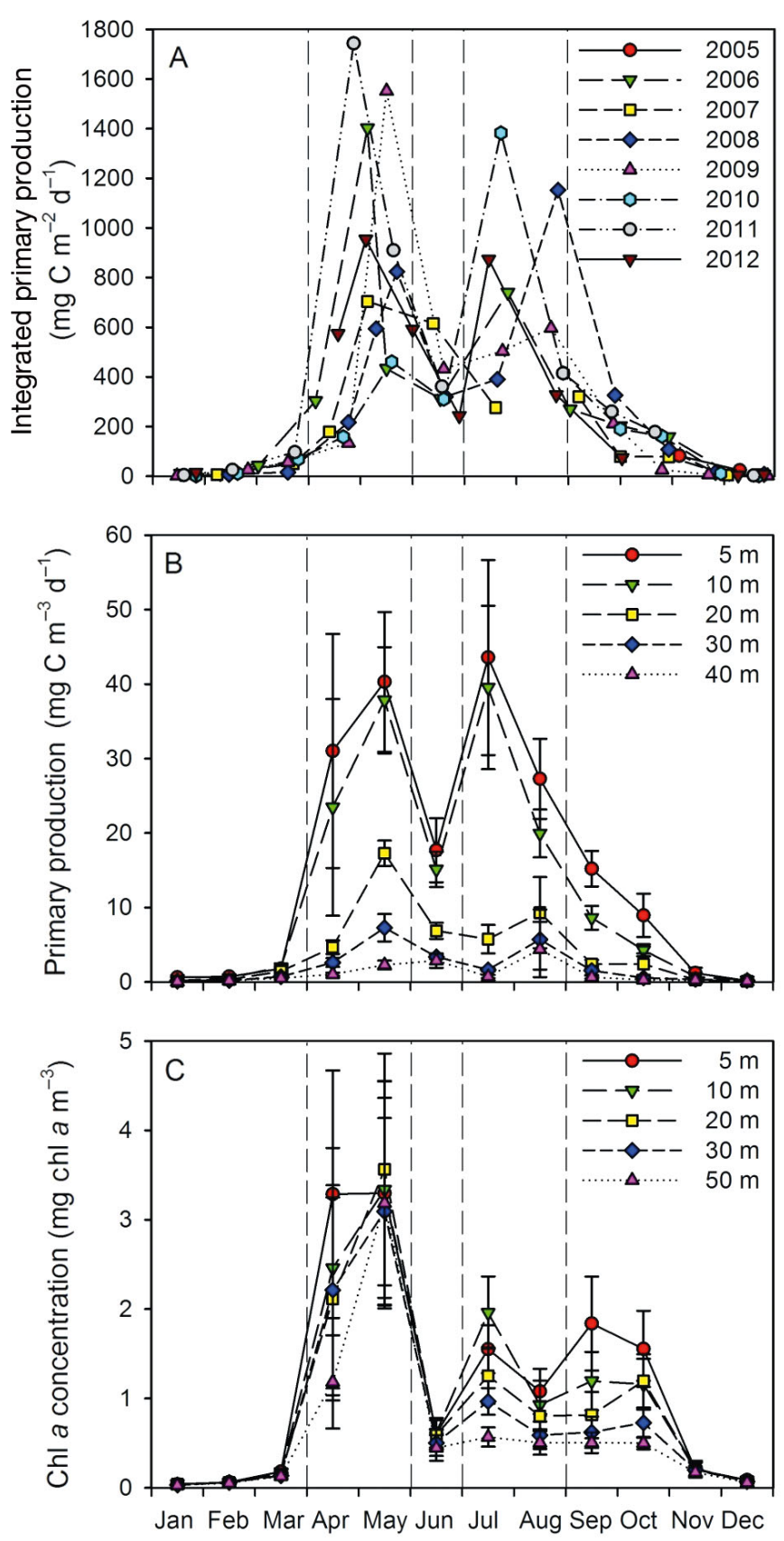

Fig. 3. Mean $( \pm \mathrm{SE})$ monthly $(\mathrm{A})$ integrated primary production (from 0-45 m) in 2005 to 2012, (B) primary production at 5, 10, 20, 30 and $40 \mathrm{~m}(2005-2012)$ and (C) chl a concentration at 5, 10, 20, 30 and $50 \mathrm{~m}(2005-2012)$
0.4-1.0 $\mu \mathrm{M}$ for nitrate+nitrite (subsequently referred to as nitrate), silicate and phosphate, respectively (Figs. 2B \& 4).

In spring (April/May), an abrupt increase in biomass and production was recorded every year. The upper $50 \mathrm{~m}$ of the water column showed a weak stratification (average density difference of $0.1 \mathrm{~kg} \mathrm{~m}^{-3}$ between 0 and $50 \mathrm{~m}$ in April/May) and annual maximum densities occurred due to annual intermittent dense coastal inflows from the West Greenland shelf (potential density anomalies up to $27 \mathrm{~kg} \mathrm{~m}^{-3}$ at $50 \mathrm{~m}$ during April/May; Fig. 2A). Temperature and salinity ranged from -1.0 to $2.1^{\circ} \mathrm{C}$ and 32.7 to 34.1 , respectively, in the upper $50 \mathrm{~m}$ (data not shown). Fluorescence profiles show that the spring bloom was dispersed over the $350 \mathrm{~m}$ water column (Fig. 2C) and on average $72 \%$ of $\mathrm{chl}$ a biomass was situated below $50 \mathrm{~m}$. Therefore, no general trend of biomass between depths within the upper $50 \mathrm{~m}$ was observed during the spring bloom (averages of 1.2-3.3 and 3.1-3.6 $\mathrm{mg}$ chl $a \mathrm{~m}^{-3}$ in April and May, respectively; Fig. 3C). In contrast, primary production was on average more than twice as high at 5-10 $\mathrm{m}$ compared to at $20-40 \mathrm{~m}$ and $45.1 \%$ of the total integrated primary production $(0-45 \mathrm{~m})$ was found in the upper $10 \mathrm{~m}$ (Fig. 3B). Primary production during spring significantly reduced nutrient concentrations within the upper $50 \mathrm{~m}$ (down to $0.8,0.8$ and $0.03 \mu \mathrm{M}$ for nitrate, silicate and phosphate, respectively; Figs. 2B \& 4).

The spring bloom was followed by a distinct decrease in phytoplankton biomass and production

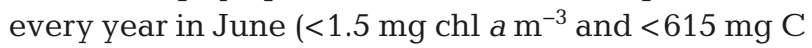
$\mathrm{m}^{-2} \mathrm{~d}^{-1}$; Table 1, Figs. 2C,D \& 3). The water column still only showed a weak stratification (Fig. 2A) and nutrients levels remained low in the upper $50 \mathrm{~m}$ (Figs. 2B \& 4).

A second annual peak in phytoplankton biomass and production was observed in the upper $50 \mathrm{~m}$ during July or August (note: no sampling in July in 2007 and 2011). In some years, this summer peak in production even exceeded the spring bloom (up to $3.5 \mathrm{mg} \mathrm{chl} \mathrm{a} \mathrm{m}{ }^{-3}$ and $1383 \mathrm{mg} \mathrm{C} \mathrm{m}^{-2} \mathrm{~d}^{-1}$, respectively; Table 1, Figs. 2C,D \& 3A). The summer blooms coincided with the development of a pycnocline within the upper $20 \mathrm{~m}$ of the water column (average density difference of $5.0 \mathrm{~kg} \mathrm{~m}^{-3}$ between 0 and $50 \mathrm{~m}$ in August), which is strong enough to withstand the intense tidal mixing (Fig. 2A). This pycnocline is a result of the seasonal increase in the glacial meltwater runoff to the fjord (van As et al. 2014). The strength of the pycnocline usually peaked in August with temperatures up to $8.3^{\circ} \mathrm{C}$ and salinities down to 18.5 in surface waters (potential density anomalies 

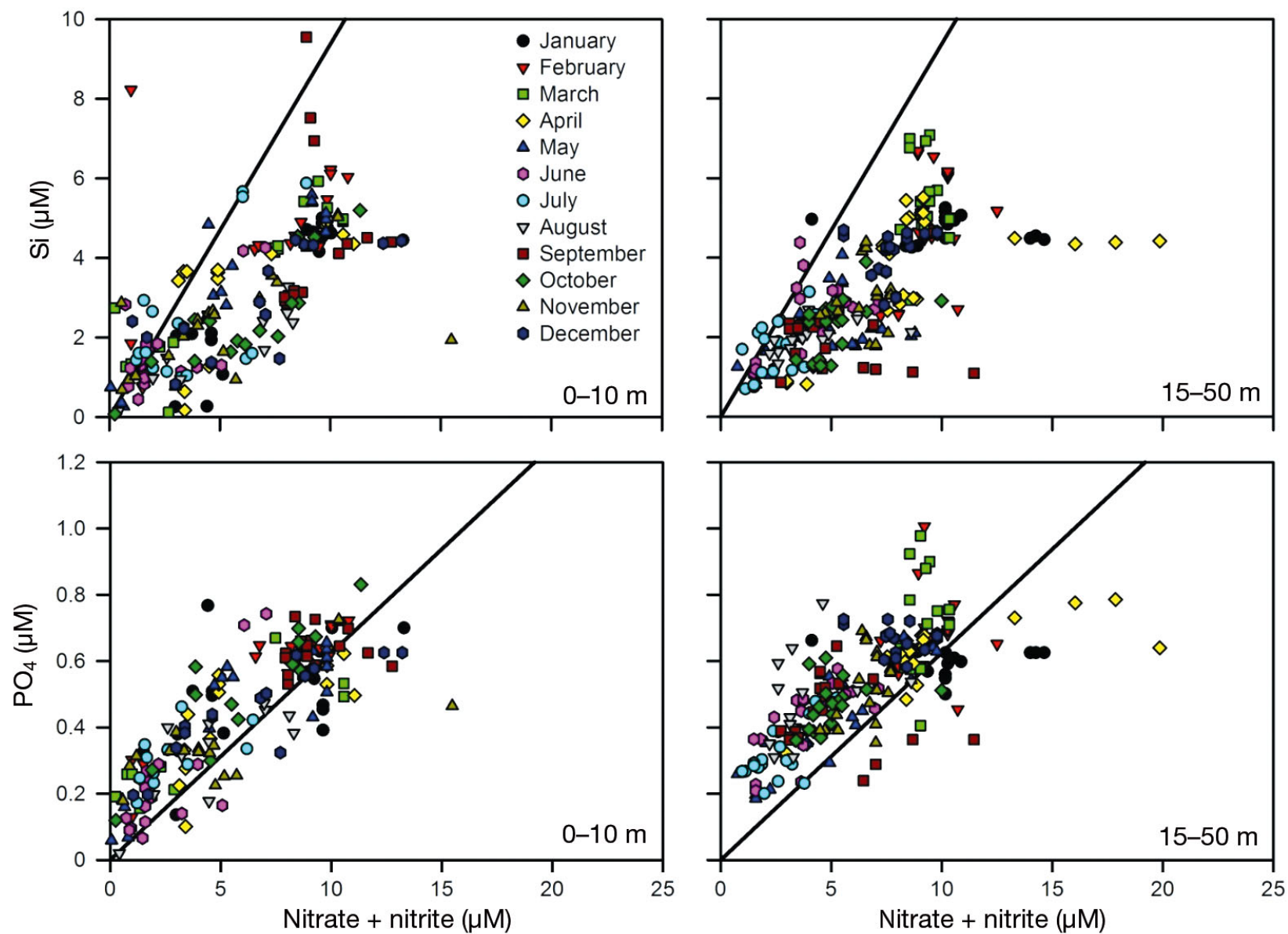

Fig. 4. Silicate $(\mathrm{Si})$ vs. nitrate + nitrite $(\mu \mathrm{M})$ and phosphate $\left(\mathrm{PO}_{4}\right)$ vs. nitrate + nitrite $(\mu \mathrm{M})$ concentrations at $0-10 \mathrm{~m}$ and $15-50 \mathrm{~m}$ during 2005-2012. Lines represent the Redfield-Brzezinski ratio (C:Si:N:P = 106:15:16:1; from Redfield 1934, 1958 and Brzezinski 1985)

down to $15 \mathrm{~kg} \mathrm{~m}^{-3}$ at $\left.1 \mathrm{~m}\right)$. A depth gradient in primary production at 5-10 $\mathrm{m}$ compared to $20-40 \mathrm{~m}$ persisted during June-August and $55.4 \%$ of the total integrated primary production (i.e. $0-45 \mathrm{~m}$ ) took place within the upper $10 \mathrm{~m}$ (Fig. 3B). Similarly, biomass levels started to depict a general depth succession from 5 to $40 \mathrm{~m}$ during summer. Nutrient levels remained low and relatively stable within the upper $50 \mathrm{~m}$ during summer, but in some years decreased even further (down to $0.3,0.3$ and $0.05 \mu \mathrm{M}$ for nitrate, silicate and phosphate, respectively; Figs. 2B \& 4).

From September onwards freshwater runoff decreased gradually, as reflected in increasing densities and weakening of the stratification (Fig. 2A). While the phytoplankton biomass remained rather stable within depths, primary production steadily decreased during September and October. Biomass and production had both returned to winter levels by November (Figs. 2C,D \& 3). Nutrient levels increased during autumn towards winter levels, though timing and level of increase varied between years (Figs. 2B \& 4).
A comparison of in situ nutrient ratios with the Redfield-Brzezinski ratios (C:Si:N:P = 106:15:16:1; from Redfield 1934, 1958 and Brzezinski 1985) is depicted in Fig. 4. In the ratio of phosphate to nitrate, the majority of data points are above but lying parallel to the Redfield-Brzezinski ratio. The ratio of silicate to nitrate showed the majority of data points below the Redfield-Brzezinski ratio. Comparison of the major nutrients suggests nitrate limitation of the primary producers prior to phosphate, while silicate may become limited prior to nitrate for silicate dependent species, given their nutrient uptake follows the Redfield-Brzezinski ratio.

\section{Interannual variation}

Integrated primary production values and average nutrient concentrations from each month during 2005-2012 are summarized in Table 1. Interannual variation in biomass, production and hydrographic 
Table 1. Integrated primary production ( $\mathrm{PP} ; \mathrm{mg} \mathrm{C} \mathrm{m}^{-2} \mathrm{~d}^{-1}$ from $0-45 \mathrm{~m}$ ) and average nutrient concentrations $(\mu \mathrm{M}$ from $0-50 \mathrm{~m}$; silicate, $\mathrm{Si}_{i}$ phosphate, $\mathrm{PO}_{4}$ i nitrate + nitrite, $\mathrm{NO}_{\mathrm{x}}$ ) for each month during 2005-2012. Integrated annual primary production (Ann. $\mathrm{PP} ; \mathrm{g} \mathrm{C} \mathrm{m}^{-2} \mathrm{yr}^{-1}$ from $0-45 \mathrm{~m}$ in 2006-2012) is presented in the right column. Blank cells represent either no or missing data

\begin{tabular}{|c|c|c|c|c|c|c|c|c|c|c|c|c|c|}
\hline & Jan & Feb & Mar & Apr & May & Jun & Jul & Aug & Sep & Oct & Nov & Dec & Ann. PP \\
\hline \multicolumn{14}{|l|}{2005} \\
\hline $\mathrm{PP}$ & & & & & & & & & & & 82.2 & 23.8 & \\
\hline $\mathrm{PO}_{4}$ & & & & & & & & & & & 0.37 & & \\
\hline $\mathrm{NO}_{\mathrm{x}}$ & & & & & & & & & & 4.1 & 4.78 & 7.29 & \\
\hline $\mathrm{Si}$ & & & & & & & & & & & 2.63 & 3.6 & \\
\hline \multicolumn{14}{|l|}{2006} \\
\hline PP & 10.4 & 10.5 & 42.6 & 303.3 & 1402 & 312.1 & 739.9 & 270 & 202.4 & 158.8 & 11.5 & & 84.6 \\
\hline $\mathrm{PO}_{4}$ & 0.62 & 0.77 & 0.63 & 0.65 & 0.29 & 0.42 & 0.24 & 0.29 & 0.25 & 0.37 & 0.42 & & \\
\hline $\mathrm{NO}_{\mathrm{x}}$ & 12.5 & 10.11 & 9.14 & 8.73 & 2.13 & 3.63 & 1.38 & 2.63 & 6.3 & 3.97 & 6.86 & & \\
\hline $\mathrm{Si}$ & 4.44 & 4.54 & 4.68 & 4.98 & 1.76 & 3.59 & 0.82 & 1.96 & 1.24 & 1.21 & 1.75 & & \\
\hline \multicolumn{14}{|l|}{2007} \\
\hline PP & & 6.8 & 50.4 & 178.9 & 703.7 & 615.2 & 276.2 & 319.9 & 78.4 & 78.1 & 4.5 & 5.1 & 94.4 \\
\hline $\mathrm{PO}_{4}$ & & 0.53 & 0.57 & 0.59 & 0.44 & 0.32 & 0.37 & & 0.4 & 0.5 & 0.64 & 0.7 & \\
\hline $\mathrm{NO}_{\mathrm{x}}$ & & 8.19 & 8.23 & 8.39 & 7.18 & 1.41 & & & & & & 6.56 & \\
\hline $\mathrm{Si}$ & & 2.55 & 2.93 & 2.93 & 1.83 & 1.02 & 1.06 & & 1.91 & 2.15 & 4.12 & 4.33 & \\
\hline \multicolumn{14}{|l|}{2008} \\
\hline PP & & 7 & 16.1 & 216.6 & 824 & 319.7 & 390.2 & 1152.5 & 326 & 107.6 & 15.1 & 7.6 & 92.1 \\
\hline $\mathrm{PO}_{4}$ & & & 0.81 & 0.68 & 0.62 & 0.41 & 0.29 & 0.39 & 0.31 & 0.46 & 0.65 & 0.67 & \\
\hline $\mathrm{NO}_{\mathrm{x}}$ & & 8.27 & 9.01 & 14.55 & 8.2 & 5.27 & 1.93 & 3.35 & 2.6 & 5.7 & 6.57 & 7.65 & \\
\hline $\mathrm{Si}$ & 5.48 & 6.08 & 7.4 & 4.38 & 2.08 & 2.35 & 2.46 & 2.22 & 1.28 & 1.81 & 4.25 & 4.25 & \\
\hline \multicolumn{14}{|l|}{2009} \\
\hline $\mathrm{PP}$ & 1.2 & 25.4 & 56.2 & 134.1 & 1552 & 431.9 & 503.7 & 596.9 & 211.4 & 25.7 & 6.3 & 2.3 & 99.8 \\
\hline $\mathrm{PO}_{4}$ & 0.57 & 0.6 & 0.63 & 0.58 & 0.21 & 0.23 & 0.28 & 0.51 & 0.51 & 0.43 & 0.55 & 0.6 & \\
\hline $\mathrm{NO}_{\mathrm{x}}$ & 10.4 & 9.91 & 9.47 & 9.05 & 2.04 & 2.17 & 2.42 & 3.07 & 4.06 & 4.32 & 6.87 & 8.88 & \\
\hline $\mathrm{Si}$ & 4.87 & 4.97 & 5.19 & 5.42 & 1.08 & 1.34 & 1.92 & 1.49 & 2.09 & 2.48 & 2.93 & 4.53 & \\
\hline \multicolumn{14}{|l|}{2010} \\
\hline PP & 1.3 & 11.8 & 68.6 & 158.4 & 460.5 & 310.2 & 1382.5 & 415.5 & 189.7 & 160.7 & 10.9 & 1.9 & 107.9 \\
\hline $\mathrm{PO}_{4}$ & 0.49 & 0.7 & & & 0.54 & 0.55 & 0.25 & 0.34 & 0.34 & 0.41 & 0.56 & 0.63 & \\
\hline $\mathrm{NO}_{\mathrm{x}}$ & 9.93 & 10.27 & 9.56 & 7.5 & 5.16 & 5.11 & 2.63 & 2.32 & 2.84 & 4.87 & 7.96 & 7.97 & \\
\hline $\mathrm{Si}$ & 4.97 & 6.11 & 5.51 & 4.22 & 3.59 & 3.09 & 1.57 & 1.9 & 2.43 & 2.65 & 3.13 & 3.01 & \\
\hline \multicolumn{14}{|l|}{2011} \\
\hline PP & 4.4 & 25.3 & 96.7 & 1743.3 & 909.8 & 360.8 & & 414.5 & 259.8 & 177.5 & & 2.6 & 139.1 \\
\hline $\mathrm{PO}_{4}$ & 0.64 & 0.67 & 0.74 & 0.37 & 0.44 & 0.47 & 0.3 & 0.38 & 0.38 & 0.35 & & 0.64 & \\
\hline $\mathrm{NO}_{\mathrm{x}}$ & 9.02 & 9.21 & 10.34 & 4.16 & 5.06 & 4.24 & 1.63 & 3.97 & 3.6 & 4.48 & & 9.97 & \\
\hline $\mathrm{Si}$ & 4.3 & 4.57 & 4.97 & 1.11 & 1.36 & 2.1 & 0.89 & 2.95 & 1.44 & 1.41 & & 4.6 & \\
\hline \multicolumn{14}{|l|}{2012} \\
\hline PP & 14.8 & & & 573.2 & 953.8 & 243 & 873 & 327.4 & 73.8 & & & 7 & 108.2 \\
\hline $\mathrm{PO}_{4}$ & 0.61 & & 0.64 & 0.42 & 0.47 & 0.37 & 0.36 & 0.86 & 4.31 & 0.55 & & 1.6 & \\
\hline $\mathrm{NO}_{\mathrm{x}}$ & 7.9 & & 8.07 & 7.04 & 4.68 & 1.82 & 1.05 & 0.3 & 0.3 & 2.61 & & 6.32 & \\
\hline $\mathrm{Si}{ }^{\wedge}$ & 4.83 & & 5.68 & 4.03 & 3.46 & 3.23 & 3.45 & 4.47 & 2.87 & 3.43 & & 4.74 & \\
\hline
\end{tabular}

conditions of the area was observed. Modest variation was observed during winter when biomass and production was low. In contrast, significant interannual variation in intensity of the spring bloom occurred, ranging from 0.06 to $11.8 \mathrm{mg} \mathrm{chl} \mathrm{a} \mathrm{\textrm {m } ^ { - 3 }}$ and a productivity of 134 to $1743 \mathrm{mg} \mathrm{C} \mathrm{m}^{-2} \mathrm{~d}^{-1}$ during 2006-2012 (Figs. 2C,D \& 3). Surprisingly low interannual variation was observed during June, whereas the intensity of the summer bloom also varied significantly (Table 1, Fig. 3). We did not observe a sub-surface chlorophyll maximum in any season (Fig. 3C).

Estimates of total annual primary production showed relatively low interannual variation (mean \pm $\mathrm{SE}$ ) $104 \pm 7 \mathrm{~g} \mathrm{C} \mathrm{m}^{-2} \mathrm{yr}^{-1}$ (ranging from 84.6 to $139 \mathrm{~g} \mathrm{C}$ $\mathrm{m}^{-2} \mathrm{yr}^{-1}$; Table 1$)$, with $46.7 \pm 1.7 \%$ of total primary production (i.e. $0-45 \mathrm{~m}$ ) occurring within the upper $10 \mathrm{~m}$ of the water column (Fig. 3). 


\section{DISCUSSION}

\section{General patterns in primary production}

This paper represents one of the few long-term studies ( $7 \mathrm{yr}$ ) on seasonality in pelagic primary productivity, algal biomass, inorganic nutrients and hydrographic conditions in the Arctic. Over the $7 \mathrm{yr}$ that we sampled (2006-2012, Table 1) the productive season lasted from April to October and was characterized by 3 main phases, shown in Fig. 5. Phase I represents the yearly reoccurring spring bloom in April/May. The spring bloom was always followed by a transition period in June (Phase II) of reduced phytoplankton biomass and production. Phase III is characterized by a second primary production peak in July or August, and continues to the end of the productive season in October. Hereafter, a low-productive winter situation (November-March) sets in.

In the present study, seasonal patterns of phytoplankton productivity and biomass differ from the classical Arctic pelagic pattern, which often describe a high spring peak followed by depressed levels in summer due to nutrient limitation, and a smaller secondary peak in fall at the weakening of surface stratification (e.g. Andersen 1981, Falk-Petersen et al. 2007, Leu et al. 2011). Our observations are similar to a time series on pelagic primary production by Smidt

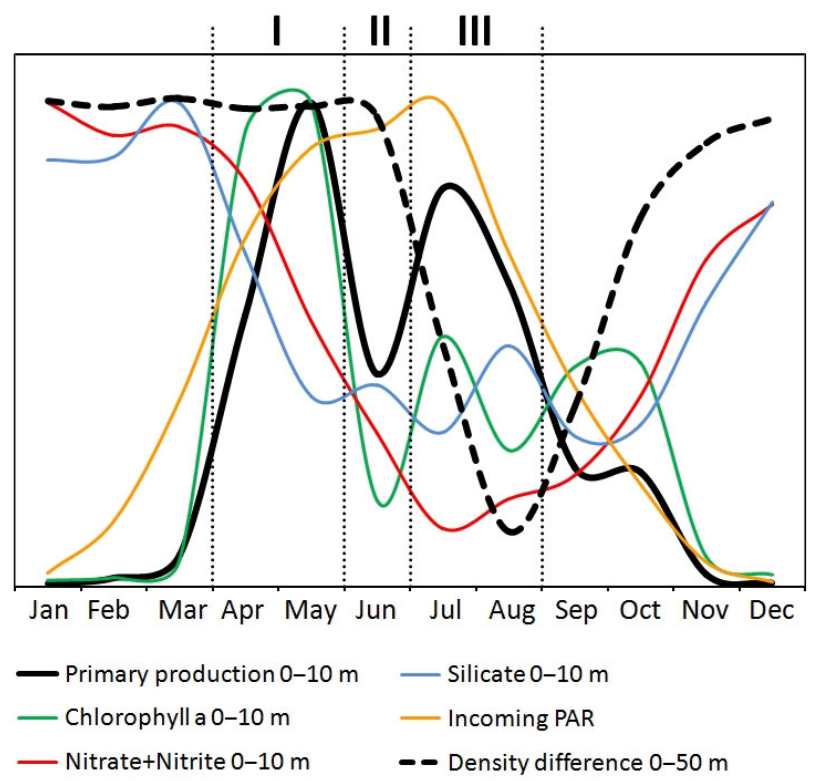

Fig. 5. A conceptual illustration of primary production $(0-10 \mathrm{~m})$, incoming PAR, nitrate+nitrite and silicate concentrations $(0-10 \mathrm{~m})$, chl a concentration $(0-10 \mathrm{~m})$, and density difference between 0 and $50 \mathrm{~m}$. Illustrations are based on data presented in the previous figures
(1979) from 1955 to 1967 at the same sampling station and also to a recent study in a glacier influenced fjord in Alaska (Etherington et al. 2007), which also revealed a high peak in primary production in spring followed by a secondary high peak in summer. We hypothesise that the timing, duration and magnitude of the glacial freshwater runoff are likely to be important for primary production dynamics in such Arctic systems. These potential relations are discussed below.

\section{Phase I: Increasing day length triggers the spring bloom}

The renewal of nutrients by winter mixing followed by increasing incoming solar radiation and establishment of a weak surface stratification trigger the phytoplankton spring bloom (Fig. 5; Smith \& Sakshaug 1990, Nielsen \& Hansen 1995, Jensen et al. 1999, Rysgaard \& Glud 2007).

The weak surface stratification observed during spring is driven by insolation, air-sea heat exchange and early ice melt in the inner-fjord and modest terrestrial runoff, forming a fresher out-fjord surface current reinforced by deeper dense coastal inflows pushing fjord waters outwards (Mortensen et al. 2011, 2014).

Favourable conditions during April and May, therefore, appear to lead to an intense biomass buildup and a strong peak in primary production at the sampling station, often revealing the highest annual production levels of the seasonal productivity (Table 1, Fig. 5). However the dispersal of algae cells throughout the entire water column (Fig. 2C), due to tidal diapycnal mixing at the sampling station, indicates short retention time in the photic zone, suggesting that the biomass is, at least partly, building up elsewhere and is advected to the station by the outfjord currents. It therefore also stands to reason that the decrease in nutrient levels during spring is likely the result of both local production and production during transit in the out-fjord surface current. In a recent study by Calbet et al. (2011) it was suggested that little of the primary production generated near the glacier is exported out of the fjord. It seems unlikely, however, that the observed high levels of production in April/May in the outer-fjord region could be sustained without the import of phytoplankton biomass from areas further inside the fjord where a more stable water column prevails.

The observed decrease in nitrate and silicate in the upper water column is thought to be a result of the 
stratification combined with primary production (Figs. 4 \& 5), which is typical for the Arctic postbloom period (Platt et al. 1987, Smith \& Sakshaug 1990, Nielsen \& Hansen 1995, Calbet et al. 2011).

\section{Phase II: Transition period between the spring and summer bloom with low primary production}

The transition period in June signals the termination of the spring bloom at the outer-sill region. We observed a strong decrease in nutrient levels (Fig. 2B) and a change in nutrient ratios during the spring bloom (Figs. 4 \& 5). Nutrient depletion is commonly recognized as the principal factor in terminating spring phytoplankton blooms, often leading to a subsequent change in phytoplankton species composition (e.g. Carmack \& Wassmann 2006). The transition period in June did actually depict a shift in phytoplankton species composition (in terms of number) from a dominance of the haptophyte Phaeocystis sp. and diatoms towards a community mainly comprised of diatoms (e.g. Chaetoceros spp. and Thalassiosira spp.; D. Krawczyk unpubl. ).

However, biomass specific productivity ( $\mathrm{mg} \mathrm{C} \mathrm{mg}$ chl $a^{-1} \mathrm{~d}^{-1}$ ) of the phytoplankton at the fjord entrance continued at a high level during this phase (data not shown), suggesting an explanation other than nutrient limitation as a reason for the low primary production during Phase II.

Zooplankton grazing could potentially account for the decrease in phytoplankton biomass observed during the transition period (Calbet et al. 2011, Arendt et al. 2013, Agersted \& Nielsen 2014). A recent study has shown that the grazing by the herbivorous Calanus spp. peaks in June (Arendt 2011) and high abundances of krill are found in Godthåbsfjord during midsummer (Agersted \& Nielsen 2014). In addition, a study on microzooplankton revealed a strong grazing on phytoplankton during June, particularly in the middle part of Godthåbsfjord (Calbet et al. 2011). Thus, a continued out-fjord transport of surface waters and intensive zooplankton grazing could be responsible for the observed reduction in phytoplankton biomass during June.

Alternatively, this recurring event in June is hypothesised to be an effect of post-bloom nutrient depletion further inside the fjord where a more stable water column is present, preventing renewal of nutrients from below (Mortensen et al. 2011). An out-fjord surface current would then bring water masses with low levels of phytoplankton (and nutrients) to the outer-sill region, where tidal diapycnal mixing ob- literates nutrient depletion in surface waters (Mortensen et al. 2014). The mechanisms behind the recurring decrease in phytoplankton biomass and production in June are not clear at this point, but nutrient depletion and zooplankton grazing further inside the fjord may play a significant role. Changes in the ratios between nutrients and a shift in species composition are also likely to be involved.

\section{Phase III: Glacial freshwater discharge triggers the summer bloom}

The second annual primary production peak observed in July is defined as the summer bloom. The peak corresponds to an increase in phytoplankton biomass and high productivity (Table 1, Figs. 3 \& 5). The start of the summer bloom is consistent with strengthening of the pycnocline that builds up due to the onset of increased meltwater runoff from the Greenland Ice Sheet. The mechanism behind this observation is difficult to determine with only one sampling station, but the consistency in this event between sampling years suggests it to be related to hydrographic conditions (Fig. 5). Therefore we suggest that the runoff from the Greenland Ice Sheet could be equivalent to other processes initiating or contributing to blooming in other marine systems, such as winter mixing and seasonal insolation (e.g. Behrenfeld et al. 2013, Carmack \& Wassmann 2006). One hypothesis could simply be that reduced vertical mixing, and increased retention time of algal cells in the photic zone, allows a build-up of phytoplankton biomass at the sampling station, resulting in an increase in total primary production (e.g. Nielsen \& Hansen 1995, Jensen et al. 1999). However, nutrient levels remained relatively constant during summer. Moreover, the algal biomass remained relatively high during July-October (Table 1, Figs. 3 \& 5) despite a drop in productivity during the same period (Table 1). These observations, together with the fact that the timing of the increase in phytoplankton biomass ( $\mathrm{chl}$ a) and production in July-August seemed to closely reflect the onset of freshwater runoff, again call for a closer look at fjord-scale oceanography.

A description of how glacial freshwater discharge from the Greenland Ice Sheet drives a specific summer fjord circulation mode in Godthåbsfjord was recently provided by Mortensen et al. (2014). The circulation mode could be responsible for renewal of nutrients by 2 processes. (1) Discharge from the ice sheet occurs as subglacial freshwater being released to the inner section of the fjord below the marine ter- 
minating tidewater outlet glacier (down to $250 \mathrm{~m}$; Motyka et al. 2003, Mortensen et al. 2013, 2014, Kjeldsen et al. 2014) and meltwater is hereby mixed with ambient fjord water at depth and lifted towards the surface due to buoyancy, inducing a stratification of the upper water column. This process brings nutrients from deeper fjord waters into the photic zone and thereby sustains a high phytoplankton productivity and biomass at the glacier front (Arendt et al. 2011, Calbet et al. 2011, Lydersen et al. 2014). (2) Due to a combination of strong tidal mixing in the outer part of the fjord and the subglacial freshwater discharge, a strong out-fjord surface current related to the onset of freshwater runoff would continue to bring water with a high phytoplankton biomass to the outer parts of the fjord throughout the summer thaw. The relative high chl a levels from July until October support this explanation. The production peak in July-August compares to or even exceeds the spring bloom, indicating that nutrients are not the primary limiting factor at this station (Table 1, Figs. 5 $\& 2 B)$. Caution should be taken when comparing the magnitude of the 2 annual primary production peaks, since variation in seasonal peak values may be due to the monthly sampling frequency not coinciding with the actual maximum production. Phytoplankton blooms in high latitude coastal areas have been shown to often last for only a few weeks (Ziemann et al. 1991, Stein \& Macdonald 2004, Madsen et al. 2008). Instead, the later reduction in primary production from August onwards seems to reflect the seasonal decline in light levels (Fig. 5).

This proposed link between primary producers and fjord hydrography is further supported by seasonal changes in phytoplankton species (D. Krawczyk unpubl.). Likewise, a shift in mesozooplankton from Calanus sp. and Cirripedia nauplii towards dominance of the harpacticoid copepod Microsetella norvegica coincide with the pulse of meltwater runoff in midsummer (Arendt et al. 2013). This suggests that the seasonal melting of the ice sheet is affecting not only phytoplankton dynamics, but the function and trophic energy transfer in this subArctic fjord ecosystem as such.

The question is to what extent an earlier onset of the glacial melt season, as a response to a future warming, will change the seasonality and magnitude of primary production. Relatively high pelagic productivity and biomass throughout the summer was reported for the warm period during the 1950-60s at the same sampling site in Godthåbsfjord (Smidt 1979). Similarly, high production and biomass values have also been reported from May to August in
Alaska (Larrance \& Chester 1979, Parsons 1986, Etherington et al. 2007) and in warm periods in the Disko Bay in West Greenland (Andersen 1981). In contrast, late-summer peaks were absent in the Disko Bay area in a relative cold period in the mid-1990s (Levinsen \& Nielsen 2002). The present observations and other Arctic studies suggest that the duration and magnitude of the summer bloom might be controlled by glacial melting events during warm periods.

The present study shows a high annual primary production (84.6 to $139.1 \mathrm{~g} \mathrm{C} \mathrm{m}^{-2} \mathrm{yr}^{-1}$; Table 1) in Godthåbsfjord, similar to other West Greenland waters (average estimates of 67 to $500 \mathrm{~g} \mathrm{C} \mathrm{m}^{-2} \mathrm{yr}^{-1}$; Steeman-Nielsen 1975, Smidt 1979, Jensen et al. 1999) and other Arctic and Atlantic shelves (average estimates of 32 and $97 \mathrm{~g} \mathrm{C} \mathrm{m}^{-2} \mathrm{yr}^{-1}$, respectively; Stein \& Macdonald 2004). The annually reoccurring spring and summer blooms challenge the classical Arctic pattern, being of equal size and the second bloom occurring in summer rather than in fall, thus adding support to findings from a glacial-influenced fjord in Alaska (Etherington et al. 2007).

Mounting evidence suggests that the Greenland Ice Sheet could represent a significant and dynamic source of nutrients (Bhatia et al. 2013, Death et al. 2013, Wadham et al. 2013) and bioavailable dissolved organic matter (Hood et al. 2009). Mortensen et al. $(2011,2014)$ showed that fjord and coastal waters act as a heat source, affecting melting of the tidewater outlet glaciers within Godthåbsfjord, which in turn drives different circulation modes within the fjord. An earlier onset and increased ablation of the Greenland Ice Sheet, due to future warming, could therefore potentially result in increased primary production and a sustained phytoplankton bloom throughout the season from spring to late-summer without a decrease in production during the observed transition period (i.e. June). Such an increase would likely propagate to the higher levels in the food web and could also result in increased $\mathrm{CO}_{2}$ drawdown from the atmosphere (Rysgaard et al. 2012)

Further work is needed to separate how physical processes (i.e. glacier runoff and fjord circulation) and biological processes (i.e. species shifts and zooplankton grazing) influence the phytoplankton productivity and biomass. The work presented here will hopefully inspire carefully designed studies on relevant spatial and temporal scales to specifically identify and test which are the drivers of the observed seasonal patterns, as well as show how these patterns change spatially throughout Godthåbsfjord and how they may change in the future. 
Acknowledgements. We thank Morten Frederiksen, Ditte M. Mikkelsen, Thomas Krogh, Louise Mølgaard, Winnie Martinsen, Pinar Kilic, Lars Heilmann, Flemming Heinrich for assistance in the field and laboratory. We also thank the personal at the Greenland Institute of Natural Resources for support throughout the study. This study and the ongoing monitoring program are funded by the Danish Energy Agency, the Danish Environmental Protection Agency, Greenland Institute of Natural Resources (GINR) and the Aage V. Jensen Charity Foundation. S.R. received funding from the Canada Excellence Research Chair (CERC) programme. D.H.S. was financially supported by the commission for scientific Research in Greenland (KVUG). The presented work is part of the ongoing marine climate monitoring program 'MarineBasis-Nuuk', which is part of the Greenland Ecosystem Monitoring Programme (www.G-E-M.dk). 'MarineBasis-Nuuk', along with the parallel programme 'MarineBasisZackenberg' in NE Greenland is managed by Greenland Climate Research Centre and GINR (www.natur.gl).

\section{LITERATURE CITED}

Agersted MD, Nielsen TG (2014) Krill diversity and population structure along the sub-Arctic Godthåbsfjord, SW Greenland. J Plankton Res 36:800-815

Andersen O (1981) The annual cycle of plankton primary production and hydrography in the Disko Bugt area, West Greenland. Meddr Grønland 205:1-25

Arendt KE (2011) Plankton community structure in a West Greenland fjord. PhD Thesis, Greenland Climate Research Centre, Greenland Institute of Natural Resources, Nuuk

Arendt KE, Nielsen TG, Rysgaard S, Tönneson K (2010) Differences in plankton community structure along the Godthåbsfjord, from the Greenland Ice Sheet to offshore waters. Mar Ecol Prog Ser 401:49-62

> Arendt KE, Dutz J, Jónasdóttir SH, Jung-Madsen S, Mortensen J, Møller EF, Nielsen TG (2011) Effects of suspended sediments on copepods feeding in a glacial influenced sub-Arctic fjord. J Plankton Res 33:1526-1537

> Arendt KE, Juul-Pedersen T, Mortensen J, Blicher ME, Rysgaard S (2013) A 5-year study of seasonal patterns in mesozooplankton community structure in a sub-Arctic fjord reveals dominance of Microsetella norvegica (Crustacea, Copepoda). J Plankton Res 35:105-120

> Attard KM, Glud RN, McGinnis DF, Rysgaard S (2014) Seasonal rates of benthic primary production in a Greenlandic fjord measured by aquatic eddy-correlation. Limnol Oceanogr 59:1555-1569

> Behrenfeld MJ, Doney SC, Lima I, Boss ES, Siegel DA (2013) Annual cycle of ecological disturance and recovery underlying the subarctic Atlantic spring plankton bloom. Global Biogeochem Cycles 27:526-540

> Bhatia M, Kujawinski EB, Das SB, Breier CF, Henderson PB, Charette MA (2013) Greenland meltwater as a significant and potential bioavailable source of iron to the ocean. Nat Geosci 6:274-278

Braman RS, Hendrix SA (1989) Nanogram nitrite and nitrate determination in environmental and biological materials by vanadium(III) reduction with chemiluminescense detection. Anal Chem 61:2715-2718

Brzezinski MA (1985) The Si:C:N ratio of marine diatoms: interspecific variability and the effect of some environmental variables. J Phycol 21:347-357
Calbet A, Riisgaard K, Saiz E, Zamora S, Stedmon C, Nielsen TG (2011) Phytoplankton growth and microzooplankton grazing along a sub-Arctic fjord (Godthåbsfjord, west Greenland). Mar Ecol Prog Ser 442:11-22

> Carmack E, Wassmann P (2006) Food webs and physicalbiological coupling on pan-Arctic shelves: unifying concepts and comprehensive perspectives. Prog Oceanogr 71:446-477

> Coello-Camba A, Augustí S, Vaqué D, Holding J, Arrieta JM, Wassmann P, Duarte CM (2014) Experimental assessment of temperature thresholds for Arctic phytoplankton communities. Estuar Coast, doi:10.1007/s12237014-9849-7

- Death R, Wadham JL, Monteiro F, Le Brocq AM and others (2013) Antarctic Ice Sheet fertilises the Southern Ocean. Biogeosci Discuss 10:12551-12570

- Etherington L, Hooge PN, Hooge ER (2007) Oceanography of Glacier Bay, Alaska: implications for biological patterns in a glacial fjord estuary. Estuar Coast 30:927-944

Falk-Petersen S, Timofeev S, Pavlov V, Sargent JR (2007) Climate variability and the effect on Arctic food chains. The role of Calanus. In: Ørbæk JR, Tombre T, Kallenborn R, Hegseth E, Falk-Petersen S, Hoel AH (eds) Arcticalpine ecosystems and people in a changing environment. Springer, Berlin, p 147-166

Glud RN, Kühl M, Wenzhöfer F, Rysgaard S (2002) Benthic diatoms of a high Arctic fjord (Young Sound, NE Greenland): importance for ecosystem primary production. Mar Ecol Prog Ser 238:15-29

Glud RN, Berg P, Hume A, Batty P, Blicher ME, Lennert K, Rysgaard S (2010) Benthic $\mathrm{O}_{2}$ exchange rates across hard-bottom sediments as quantified by eddy correlation in a sub-Arctic fjord system. Mar Ecol Prog Ser 417:1-12

Grasshoff K, Erhardt M, Kremling K (1983) Methods of seawater analysis. Verlag Chemie, Weinheim

Grøntved J, Seidenfaden G (1938) The phytoplankton of the waters west of Greenland. The Godthaab Expedition 1928. Meddr Grønland 82:1-380

Hood E, Fellman J, Spencer RGM, Hernes PJ, Edwards R, D'Amore D, Scott D (2009) Glaciers as a source of ancient and labile organic matter to the marine environment. Nature 462:1044-1047

> Jensen HM, Pedersen L, Burmeister A, Hansen BW (1999) Pelagic primary production during summer along 65 to $7^{\circ} \mathrm{N}$ off West Greenland. Polar Biol 21:269-278

> Johnson KM, Sieburth JM, Williams PJ, Brändström L (1987) Coulometric total carbon dioxide analysis for marine studies: automation and calibration. Mar Chem 21: $117-133$

> Kjeldsen KK, Mortensen J, Bendtsen J, Petersen D, Lennert K, Rysgaard S (2014) Ice-dammed lake drainage cools and raises surface salinities in a tidewater outlet glacier fjord, west Greenland. J Geophys Res Earth Surf 119: 1310-1321

Krause-Jensen D, Kühl M, Christensen PB, Borum J (2007) Benthic primary production in Young Sound, Northeast Greenland. In: Rysgaard S, Glud R (eds) Carbon cycling in Arctic marine ecosystem: case study Young Sound. Meddelelser om Grønland, Bioscience 58. Commission of Scientific Research in Greenland, Copenhagen, p 160-173

Larrance JD, Chester AJ (1979) Source, composition, and flux of organic detritus in lower Cook Inlet. U.S. Department Commerce, NOAA. Outer Continental Shelf Environmental Assessment Program Final Report 46:1-71 
Legendre L, Martineau MJ, Therriault JC, Demers S (1992) Chlorophyll a biomass and growth of sea-ice microalgae along a salinity gradient (southeastern Hudseon Bay, Canadian Arctic). Polar Biol 12:445-453

$>$ Leu E, Søreide JE, Hessen DO, Falk-Pedersen S, Berge J (2011) Consequences of changing sea-ice cover for primary production and secondary producers in the European Arctic shelf seas: timing, quantity and quality. Prog Oceanogr 90:18-32

> Levinsen H, Nielsen TG (2002) The trophic role of marine pelagic ciliates and heterotrophic dinoflagellates in arctic and temperate coastal ecosystems: a cross-latitude comparison. Limnol Oceanogr 47:427-439

Levinsen H, Jefferson TT, Nielsen TG, Hansen BW (2000) On the trophic coupling between protists and copepods in arctic marine ecosystems. Mar Ecol Prog Ser 204: 65-77

> Lydersen C, Assmy P, Falk-Petersen S, Kohler J and others (2014) The importance of tidewater glaciers for marine mammals and seabirds in Svalbard, Norway. J Mar Syst 129:452-471

Madsen SD, Nielsen TG, Hansen BW (2008) Annual population development and production by small copepods in Disko Bay, western Greenland. Mar Biol 155:63-77

> Mortensen J, Lennert K, Bendtsen J, Rysgaard S (2011) Heat sources for glacial melt in a sub-Arctic fjord (Godthåbsfjord) in contact with the Greenland Ice Sheet. J Geophys Res 116:C01013, doi:10.1029/2010JC006528

- Mortensen J, Bendtsen J, Motyka RJ, Lennert K, Truffer M, Fahnestock M, Rysgaard S (2013) On the seasonal freshwater stratification in the proximity of fast-flowing tidewater outlet glaciers in a sub-Arctic sill fjord. J Geophys Res Oceans 118:1382-1395

Mortensen J, Bendtsen J, Lennert K, Rysgaard S (2014) Seasonal variability of the circulation system in a west Greenland tidewater outlet glacier fjord, Godthåbsfjord $\left(64^{\circ} \mathrm{N}\right)$. J Geophys Res Earth Surf 119:2591-2603

> Motyka R, Hunter L, Echelmeyer KA, Connor G (2003) Submarine melting at the terminus of a temperate tidewater glacier, LeConte Glacier, Alaska, U.S.A. Ann Glaciol 36: 57-65

> Nielsen TG, Hansen B (1995) Plankton community structure and carbon cycling on the western coast of Greenland during and after the sedimentation of a diatom bloom. Mar Ecol Prog Ser 125:239-257

Parsons TR (1986) Ecological relations. In: Hood DW, Zimmerman ST (eds) The Gulf of Alaska: physical environment and biological resources. National Oceanic and Atmospheric Administration, US Government Printing Office, Washington, DC, p 561-570

> Platt T, Harrison WG, Horne EPW, Irwin B (1987) Carbon fixation and oxygen evolution by phytoplankton in the Canadian High Arctic. Polar Biol 8:103-113

Poulsen LK, Reuss N (2002) The plankton community on Sukkertop and Fyllas Banke off West Greenland during a spring bloom and post-bloom period: hydrography, phytoplankton and protozooplankton. Ophelia 56:69-85

Redfield A (1934) On the proportions of organic derivatives in sea water and their relation to the composition of plankton. In: Daniel RJ (ed) James Johnstone memorial volume. University Press of Liverpool, p 177-192

Redfield A (1958) The biological control of chemical factors in the environment. Am Sci 46:205-221
Richter A, Rysgaard S, Dietrich R, Mortensen J, Petersen D (2011) Coastal tides in West Greenland derived from tide gauge records. Ocean Dyn 61:39-49

Rysgaard S, Glud R (eds) (2007) Carbon cycling in Arctic marine ecosystem: case study Young Sound. Meddelelser om Grønland, Bioscience 58. Commission of Scientific Research in Greenland, Copenhagen

Rysgaard S, Mortensen J, Juul-Pedersen T, Sørensen LL and others (2012) High air-sea $\mathrm{CO}_{2}$ uptake rates in nearshore and shelf areas of Southern Greenland: temporal and spatial variability. Mar Chem 128-129:26-33

Sakshaug E (2004) Primary and secondary production in the Arctic Seas. In: Stein R, Macdonald RW (eds) The organic carbon cycle in the Arctic Ocean. Springer-Verlag, Berlin, p 57-81

Smidt ELB (1979) Annual cycles of primary production and of zooplankton at Southwest Greenland. In: Rysgaard S, Glud R (eds) Meddelelser om Grønland, Bioscience 1. Commission of Scientific Research in Greenland, Copenhagen

Smith WO, Sakshaug E (1990) Polar phytoplankton. In: Smith WO (ed) Polar oceanography. Part B: chemistry, biology and geology. Academic Press, New York, NY p 477-525

Søgaard DH, Kristensen M, Rysgaard S, Glud RN, Hansen PJ, Hilligsøe KM (2010) Autotrophic and heterotrophic activity in Arctic first-year sea ice: seasonal study from Malene Bight, SW Greenland. Mar Ecol Prog Ser 419: $31-45$

Steeman-Nielsen E (1952) The use of radio-active carbon (14C) for measuring organic production in the sea. J Cons Int Explor Mer 18:117-140

Steeman-Nielsen E (1975) Marine photosynthesis with special emphasis on the ecological aspects. Elsevier, Amsterdam

Stein R, Macdonald RW (eds) (2004) The organic carbon cycle in the Arctic Ocean. Springer-Verlag, Berlin

Strickland JDH, Parsons TR (1972) A practical handbook of sea-water analysis. Fish Res Bd Can Bull 167, Ottawa

> Tang KW, Nielsen TG, Munk P, Mortensen J and others (2011) Metazooplankton community structure, feeding rate estimates, and hydrography in a meltwater-influenced Greenlandic fjord. Mar Ecol Prog Ser 434:77-90

> Tremblay JÉ, Michel C, Hobson KA, Gosselin M, Price NM (2006) Bloom dynamics in early opening waters of the Arctic Ocean. Limnol Oceanogr 51:900-912

> Tremblay JÉ, Simpson K, Martin J, Miller L, Gratton Y, Barber D, Price NM (2008) Vertical stability and the annual dynamics of nutrients and chlorophyll fluorescence in the coastal, southeastern Beaufort Sea. J Geophys Res 113:C07S90, doi:10.1029/2007JC004547

> van As D, Andersen ML, Petersen D, Fettweis X and others (2014) Increasing melt water discharge from the Nuuk region of the Greenland ice sheet and implications for mass balance (1960-2012). J Glaciol 60:314-322

Wadham J, De'ath R, Monteiro F, Tranter M, Ridgwell AJ (2013) The potential role of the Antarctic Ice Sheet in global biogeochemical cycles. Earth Env Trans R Soc Edinb 104:55-67

> Ziemann DA, Conquest LD, Olaizola M, Bienfang PK (1991) Interannual variability in the spring phytoplankton bloom in Auke Bay, Alaska. Mar Biol 109:321-333 